\title{
Martina Vranova, Zénó Vernyik and Dávid Levente Palatinus (eds.). Crime and Detection in Contemporary Culture. Szeged: Americana eBooks, 2018.
}

\author{
Renáta Zsámba
}

Crime and Detection in Contemporary Culture is an edited collection of scholarly essays which addresses a relatively long-standing debate around the genre of crime fiction, its significance in shaping the literary map of the past two hundred years, its contribution to not only popular but mainstream literature and culture as well. It is, then, no surprise, that the editors in the Introduction, immediately start outlining the traditional critical approach to the genre, which was rather hostile and discriminative. Similar to dozens of criticisms written about crime and detective fiction, the introductory paragraphs point out that this type of literature was marginalized for being labelled as escapist and lowbrow texts, cheap literature that has no literary value due to its formulaic nature or flat characterization. Furthermore, its proliferation and popularity in the book market associated the genre with mass production, low-quality writing and lower-class readership. Undoubtedly, crime fiction suffered from this narrow-minded and mean critical attitude for decades but the turn of the century brought a rapid increase in academic criticism that targeted the revision and re-interpretation of the genre which was also part of the vivid interest in cultural studies. Along with other leading critics and acclaimed authors of crime fiction, such as Stephen Knight, Charles J. Rzepka, Mary Evans, Andrew Pepper or P. D. James, the present volume also calls for and participates in the process of re-visioning and re-evaluating the status of the genre by claiming that it has always been truly contemporary in its ability to continuously re-invent itself and reflect on the social, cultural and political context of its own time since its appearance in the $19^{\text {th }}$ century. Another intriguing aspect of this type of literature lies not only in its popularity with people of all social classes or educational level, but also in its capacity to inspire writers with very different literary backgrounds. While literary critics from the 1930s did a lot to prevent the genre from rising to its deserved place, mainstream or 'serious' writers could not resist the temptation of not only becoming a fan, e.g. W.H. Auden, but felt the urge to write crime/ detective stories.

The Introduction illustrates this phenomenon with literary examples from the post-war era to hint at the genre's flexibility to cross boundaries between high-, middle- or lowbrow literature. Writers like Cormac McCarthy, Paul Auster and 
Martin Amis are mentioned as representative examples, but readers of crime fiction are fully aware of the fact that the appreciation of crime fiction by serious writers dates back to the $18^{\text {th }}$ century, to William Godwin, an acclaimed philosopher, a novelist and the author of an early mystery novel, Things As They Are; or The Adventures of Caleb Williams (1794). Nevertheless, it is only after the Second World War that crime fiction for the first time truly had the opportunity to narrow the gap between serious and popular literature, both categories being redundant and discriminative, and to invent a great diversity of forms that best suited for the representation of the post-war era regarding crime, political threats, violence, social and financial crises, or everyday life. As a result, the second half of the $20^{\text {th }}$ century gave birth to many sub-genres in literature and film, from the hard-boiled type to forensic mysteries, or the most recent form, video games.

Apart from emphasizing how rich and complex this field is, one of the goals of the present collection is to draw attention to the role that crime fiction in its numerous literary, and visual forms has come to occupy and play in contemporary society. The authors of the articles take an interdisciplinary approach to explore the selected texts, so the reader will find that the analyses are located at the intersection of various fields, such as gender, cultural, media, spatial, adaptation and medical studies, but some papers reflect on the historical and the structural methods as well. Although all of the essays submit themselves to the main goals of the collection, the editors divided them into two sections based on the area accentuated in them. Thus, section one is dedicated to crime and detection in literature, and section two examines the representation of crime in other media, such as film, television series, or computer games. Although the first section is more loosely organized in terms of themes and sub-genres than the second one, it certainly offers an insight into contemporary crime fiction as it has adapted to and satisfied various national and cultural demands with an inevitable transformation in its form and content. Thus, as the essays show, crime fiction has provided a ground for both authors and critics to address issues in relation to historical eras, national identities or political upheavals.

Markéta Gregorová, for instance, enquires into the Scottish brand of crime fiction, tartan noir, and delineates how the duality, so intrinsic to the Scottish character, features in Ian Rankin's crime novels. Michaéla Markovás article explores the connection between form and content, more precisely the reasons why the thriller form is the most suitable one to stage the Northern Ireland conflict, 'The Troubles'. Martina Vranová addresses such recurring themes in crime fiction as the nature of evil or the psychology of the characters in Ian Banks's fiction and pays special attention to the author's nihilism and the dystopian view of human nature. Petr Anténe discusses the connection between detective fiction and the 
campus novel in A. S. Byatt's Possession (1990) and Michael Dorris and Louise Erdrich's The Crown of Columbus (1991). The claim that the two genres are related is not a novelty considering Dorothy L. Sayers' campus murder mystery, Gaudy Night (1935), but the fact that the features of detective fiction have significantly "enriched the genre in the last decade of the twentieth century" (55), is a sign that Golden Age crime fiction had an immense influence on the development of campus novels in the post-war era. The first section ends with Sándor Klapcsik's essay, which insightfully demonstrates common practices in Sherlock Holmes adaptations with special regard to the fantastic. While the topic and approach are both appealing, the essay is probably too short to be crammed with long lists of productions and terminologies that might hamper understanding the main idea.

As mentioned earlier, the second section centers around the visual representation of crime in various forms of media, films, computer games, television series and digital interfaces. Unlike in the first part, the articles are more in dialogue with and complement each other. This may be attributed to the fact that all of them foreground the relation between technology and how crime fiction responds to its latest innovations, which most of the authors demonstrate through the analysis of the television series CSI. The opening article by Zoltán Dragon is truly captivating as it illustrates the latest evolution of the genre in the digital age. The author sheds light on the process of the inevitable "shift in detection paradigms" (82) in its exposure to the rapid technological development. He argues that the modern detective need not rely on the "little grey cells" any more as it happens in the classical phase, but his/ her knowledge and investigative methods are more and more defined by technology. Dávid Levente Palatinus exploits forensic crime stories, which is a relatively new and unexplored area in the criticism of crime fiction. His article is truly engaging in its details of the generic features of forensic mysteries through the example of one of the most successful television series, CSI, but he delves into a theoretical discussion about the aesthetics and visual language of forensic crime series as well by examining "the mediation of post-human anxieties about the fragmentation of the human body" (92). Zénó Vernyik's essay is undoubtedly one of the most captivating and novel approaches to the genre since it puts a video game, The Black Mirror, into focus, and argues that it can be read and interpreted as a detective story. Furthermore, he argues that analyzing this video game as a crime narrative allows him to demonstrate its ability to incorporate two different types of detective fiction: the classical and the metaphysical. Finally, Elke Weissmann joins the previous article in depicting the representation of crime in a Facebook game: CSI: Crime City. Her interest, however, lies in discussing how the original CSI series has affected the creation of additional texts, such as this particular game, in revising media practices that control the relationship between the productions and the audience. 
The present volume is an ambitious attempt to show that crime fiction has not abated during the past few decades but has occupied a central position in literature and other forms of media. The authors claim that the way crime is represented in the various sub-genres can be a key to the understanding of the ontological and epistemological concerns in modern culture. While most of the articles are a joy to read, some would have needed a more careful proofreading in order to bring the content, style and language in harmony. Nevertheless, anyone setting out to read Crime and Detection in Contemporary Culture, will eventually recognize its merits, its engagement with the latest theoretical ideas, and enjoy its witty and informative way of sharing it all with the reader. 